\title{
Corrosion of galvanized pipes in the hot water supply system
}

\author{
Alexey Andrianov ${ }^{1, *}$, and Dmitry Spitsov ${ }^{1}$ \\ ${ }^{1}$ Moscow State University of Civil Engineering, Yaroslavskoye shosse, 26, Moscow, 129337, Russia
}

\begin{abstract}
The paper describes the problem of steel pipes corrosion in domestic hot water supply systems. A case study of abnormally high rate of corrosion of galvanized steel pipes in a hot water supply system, installed in a complex of residential and public buildings, was considered. The rapid corrosion led to premature failure of these pipelines. Onsite visual inspection, chemical analysis of the tap water with LSI/RSI calculation and scanning electron microscopy and energy-dispersive X-ray spectroscopy analysis were used during this study. The basic factors that lead to pitting corrosion were established: quality of source water (its high corrosion activity), high temperature and local increase in oxygen content near the pipe surface. A possibility of microbial corrosion was also assumed.
\end{abstract}

\section{Introduction}

Despite increased use of plastic and ductile iron pipes for construction of water supply systems, steel pipes production volumes in Russia remain high due to technological advantages in laying external water supply systems, as well as high fire safety when installing internal systems. The main advantages of steel pipes are their strength, low coefficient of linear expansion, possibility to use several types of pipes connection in one network. However, low corrosion resistance of steel pipes, both ferrous and galvanized, significantly reduces the above advantages.

Galvanized steel pipes are often used without taking into account quality of tap water, as well as ignoring the requirements of standards on stabilization treatment before water is fed into the water supply network. Sometimes these mistakes lead to intense corrosion of the steel and iron pipes that has a great impact on water quality and lifetime of pipelines in water distribution systems [1-7].

Corrosion in the presence of oxygen is the main reason of destruction of equipment and steel pipes in water supply systems $[5,8,9]$. It happens both during operation, and during downtime. Oxygen influence on corrosion rate can be seen in formation of electrochemical cells with uneven aeration, in which the flow of oxygen to one part of metal surface is more than to another part. Cathodic process is localized on more aerated metal areas. At the same time, less aerated metal areas are influenced by anodic process, which leads to increased corrosion of these areas [10].

*Corresponding author: alexei-waterlab@yandex.ru 
It is known that metals corrosion is often reduced to their oxidation and conversion to oxides. In particular, iron corrosion can be described by the following simplified equation:

$$
4 \mathrm{Fe}+3 \mathrm{O}_{2}+2 \mathrm{H}_{2} \mathrm{O}=2 \mathrm{Fe}_{2} \mathrm{O}_{3} \cdot \mathrm{H}_{2} \mathrm{O}
$$

From this equation we can see that for each $1 \mathrm{mg}$ of oxygen reacted, water should receive $2.33 \mathrm{mg}$ of iron. What part of this iron will be realised in the water flow it depends on many factors $[1,5,7,8]$.

This paper considers the study of high rate corrosion in hot water supply pipes in a complex of residential and public buildings put into operation in 2012-2013. The reason for the survey was consumers' complaints about water quality and frequent failures due to holes in the main pipelines.

After one year of the water supply system operation, consumers started to complain for hot water quality, namely, for its increased turbidity, color, rusty water, unpleasant taste. The frequency of failures due to pitting corrosion in the hot water supply system (breaches and leaks on steel pipes in basements and heat points) by the end of 2014 reached 6 times per day.

The aim of the research was to identify the reasons for the unusually high corrosion rate in water supply system and to clarify the role of dissolved oxygen in this process.

\section{Materials and methods}

The treatment process of water supplied to the facility's network comprises reagent-free filtering through fast pressure and cartridge type 5-micron filters, dosing of sedimentation inhibitor, single-stage desalination at the reverse osmosis unit and disinfection with sodium hypochlorite solution. Indicators of quality of source water supplied to the water network are as follows: total salt content $-100 \ldots 200 \mathrm{mg} / 1, \mathrm{pH}-5.8 \ldots 6.8$, total hardness $-0.5 \mathrm{meq} / \mathrm{l}$, chlorides - 65...120 mg/l, sulfates - less than $2.0 \mathrm{mg} / \mathrm{l}$, calcium - $2.0 \mathrm{mg} / \mathrm{l}$, iron 0.06...0.08 mg/l, alkalinity - $0.2 \mathrm{meq} / \mathrm{l}$, Langelier Stability Index (LSI) - -2.4.. -4.0, Ryzner Stability Index (RSI) - 12.0 ... 14.2.

Water coming from the cold water supply system is heated in plate-type heat exchangers up to the required temperature $\left(+65 \ldots 67^{\circ} \mathrm{C}\right)$. Heat exchangers are installed in individual heat points of each building. Special water pretreatment for the hot water supply system was not included in the project, although in accordance with Russian construction standards, for water supplied to the hot water supply system with LSI less than 1.5 and chloride content of more than $50 \mathrm{mg} / 1$ (which is usual for water obtained after desalination unit), vacuum deaeration and silicate treatment is recommended.

Main feeding and circulating pipelines of the internal hot water supply system and pipes in the heat points are made of welded galvanized steel pipes, while risers and pipes coming to appliances in the rooms - of polypropylene multilayer pipes.

Quality parameters of hot water depended on sampling points and changed widely: $\mathrm{pH}-$ $4.1 \ldots 9.1$, iron content -0.1 to $17 \mathrm{mg} / 1$, turbidity -10 to $260 \mathrm{FTU}$, total microbial count 0 ... 3,300 CFU/ml.

Figure 1 shows photos of the pipe cross-section sample from the hot water supply system, dismounted during emergency repairs. As we can see from Fig. 1a, a layer of sediment appeared around the pipe perimeter: tubercles up to $10 \mathrm{~mm}$ thick, which resulted in a decrease of effective cross section of the $100 \mathrm{~mm}$ pipe by $36 \%$. The metal surface under sediment has deep ulcers (up to $50 \%$ of the wall thickness, Figure $1 \mathrm{~b}$ ) virtually around the entire pipe circumference. 


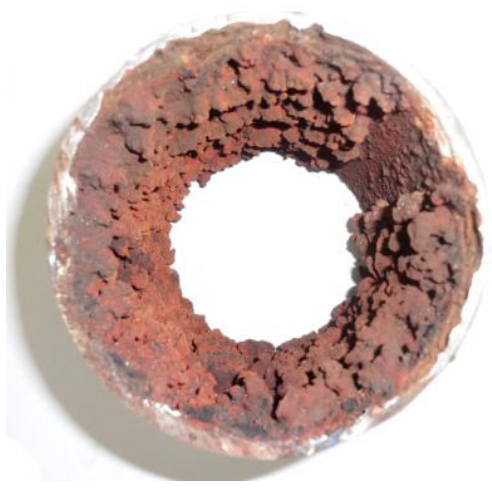

a)
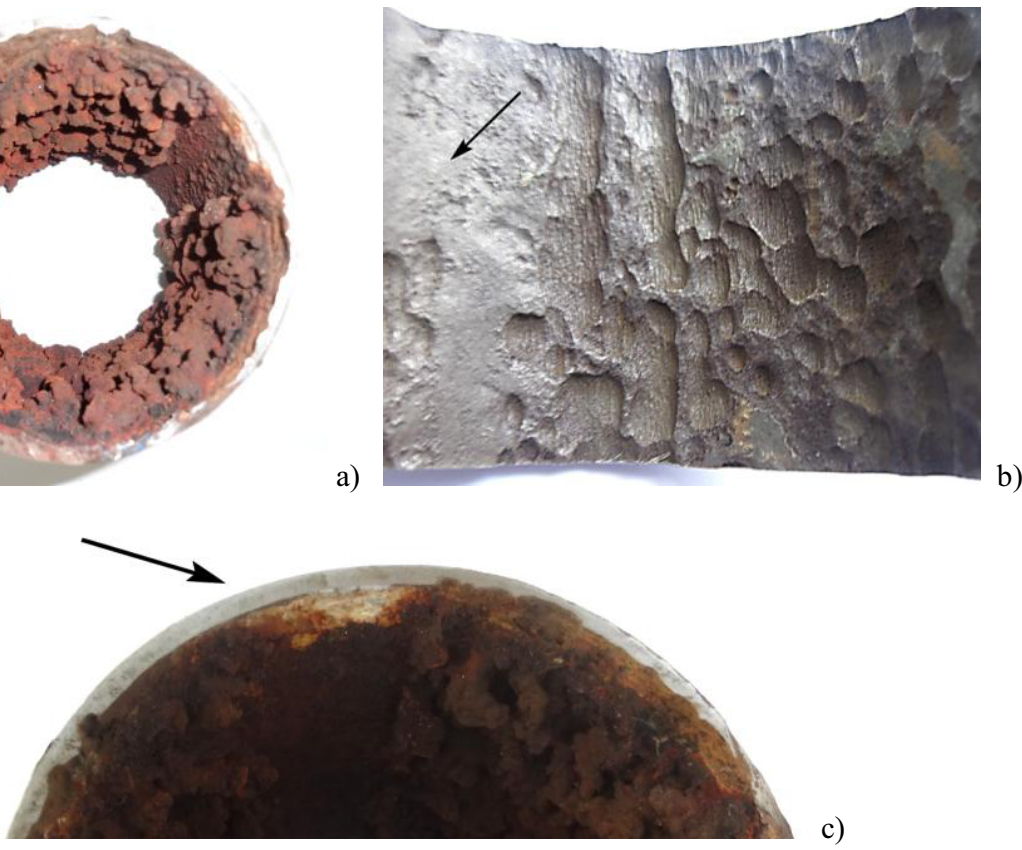

c)

Fig. 1. Pictures of the DN 100 pipe sample: a) general view; b) pipe inside surface after cleaning; c) segment of the pipe (under arrow) without traces of corrosion damage.

In recent years to study the processes occurring in steel and cast iron pipes, people are increasingly using modern methods of pipeline condition monitoring and studying morphology and composition of corrosion deposits [11], including SEM/EDS, which allows reinterpreting the observed facts.

The pipe sample (feeding pipeline, galvanized steel, DN 100), shown in Fig. 1a, was analyzed as for structure and composition of deposits (tubercles) by scanning electron microscopy and energy dispersive X-ray spectroscopy using Quanta 250 FEI with GENESIS APEX 2 EDS System with APOLLO X SDD EDAX. Color microphotos were made by optical microscope with USB digital camera.

\section{Results and discussion}

Figure 2 shows SEM images and elemental composition of corrosive sediments. The sediment mainly consists of iron oxides and hydroxides $\mathrm{Fe}(\mathrm{OH})_{2}, \mathrm{FeOOH}, \mathrm{Fe}_{3} \mathrm{O}_{4}$; sometimes the sediment contains zinc oxide being a product of destruction of piping galvanization. Carbon content is relatively low and may be related to iron carbonate and organic substances released from tap water. Generally, corrosion deposits in the investigated samples can be characterized as loose and highly porous; such a structure does not contribute to creating a protective layer on the metal surface slowing down further corrosion.

Figure 3 shows for comparison the picture of tubercles taken from pipes being in operation for 38 (Figure 3a) and 2 years (Figure $3 \mathrm{~b}$ ) respectively. The difference is that under a surface loose layer (Figure 3a) there is a solid layer - the shell [12,13], which has crystalline structure and has high resistance to diffusion of oxygen to the metal surface. This layer contains magnetite $\mathrm{Fe}_{3} \mathrm{O}_{4}$, which is recovered from $\mathrm{FeOOH}$ at oxygen content in water of less than $1 \mathrm{mg} / \mathrm{l}$, while the recovery goes due to electrochemical reactions [14]. 

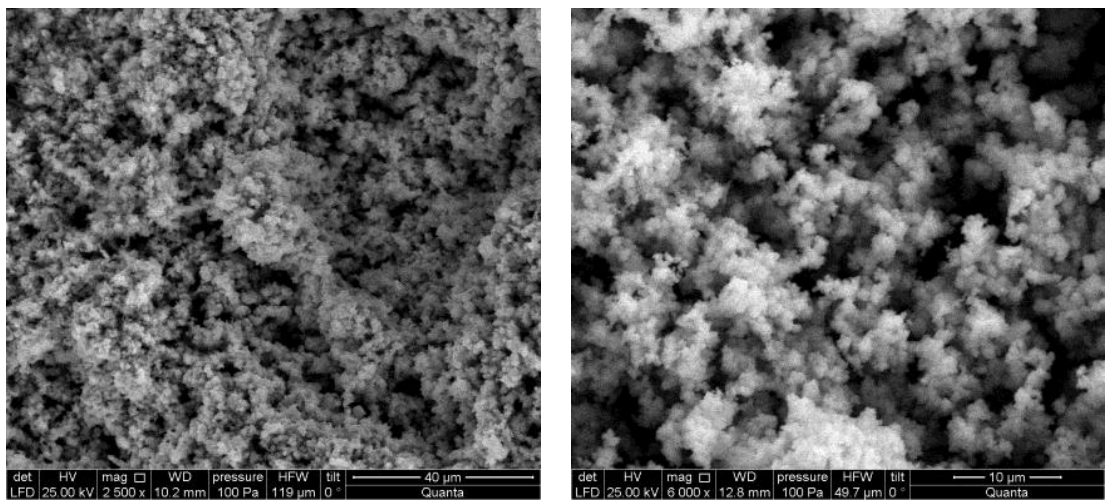

Fig. 2. Micrographs and composition of the surface of corrosion deposits for pipes DN $100 \mathrm{~mm}$ (anode area).

Table 1. Elemental composition.

\begin{tabular}{|c|c|c|c|c|}
\hline \multicolumn{5}{|c|}{ Elemental composition, $\mathbf{W t} \%$} \\
\hline $\mathrm{C}$ & $\mathrm{O}$ & $\mathrm{Fe}$ & $\mathrm{Zn}$ & $\mathrm{Na}$ \\
\hline 2.0 & 30.2 & 65.7 & $0 \ldots 2.8$ & $0 \ldots 2.6$ \\
\hline
\end{tabular}
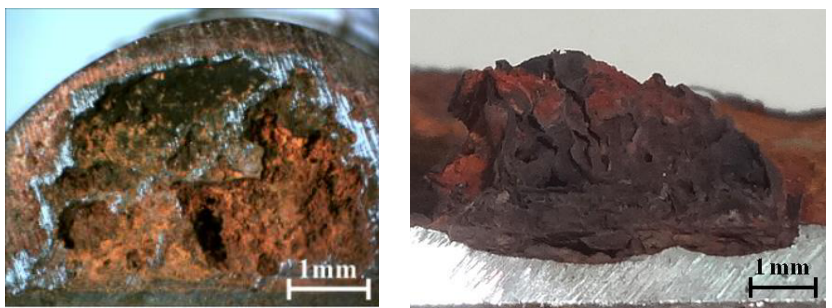

Fig. 3. Microphotos of cross sections of tubercles: a) cold water pipeline, DN $300 \mathrm{~mm}$ [13], b) hot water pipeline, DN $100 \mathrm{~mm}$.

The following conclusions can be drawn based on the analysis of water quality, the exterior condition of the steel pipes for hot and cold water supply systems and study of characteristics of corrosion scales: the main factor of the accelerated corrosion is high corrosion activity of water caused by low content of hardness salts and alkalinity in source water, as well as low pH value. The calculated LSI (-2.4 ..-4.0) and RSI (12.0..14.2) indices for source tap water coming into the network, as well as water circulating in the hot water supply system, are in the negative range, and according to this indicator, water can be defined as highly corrosive $[15,16]$. High corrosion activity is typical for desalinated water [16-18], however, cold water pipes condition was satisfactory, in contradistinction to hot water distribution pipes.

The following factors are high oxygen content and temperature of hot water $[7,16]$. This conclusion can be drawn from information on localization of corrosion damages of pipes both in cold and hot water supply systems, as corrosion with oxygen depolarization is the most common for water pipes.

The most holes observed on pipes are located at points behind local resistances on the pipeline: behind valves, places where diameter changes, bends, welded joints, risers' connection points with the main pipelines. Due to speed change, these places have local pressure differences, which lead to cavitation and its effects: release of oxygen and other 
gases from dissolved state into gaseous phase, which results in macro- and microcells of uneven aeration, as mentioned above.

Figure 1c shows a photo of the top of pipe cross section, which shows that the pipe wall at this location (indicated by an arrow) is completely free of corrosion. We can confidently say that exactly in this place water was saturated with oxygen the most, and the pipe section marked by the arrow is a cathode, while the rest of the surface is an anode. Analysis of deposits in this area has shown that they mostly consist of zinc oxide $\mathrm{ZnO}$ (see composition in Figure 4).

The deposit micrographs shown in Figure 2 refer to areas covered with loose, porous layer taken from active corrosion (anodic) portions. Chemical composition and structure of the sediment (max thickness is $1 \mathrm{~mm}$ ) taken from the cathodic area significantly differ from the previous samples. Close to the metal surface, the deposit consists of zinc oxide crystals (Figure 4a), and the surface layer contains also iron oxides (see. Figure 4b). Calcium content is negligible: within $0.5-0.6 \%$.

It should be noted that for the samples shown in Figure 2 and $4 \mathrm{a}$, deposits do not contain calcium, which in accordance with the common concept of interaction of stable water and metal pipes should be present in the deposit on their surface. Obviously, the absence of calcium is due to the fact that water hardness is less than $0.5 \mathrm{meq} / \mathrm{l}$ and alkalinity is about $0.2 \mathrm{meq} / 1$. However, our previous examinations of pipes taken from various locations of the Moscow water supply network, where water can be considered as slightly corrosive, also show that calcium content in the surface layer of sediment is not more than two percent, which is much less than calcium relative content in drinking water, and in a layer adjacent to metal there is no calcium at all [19].
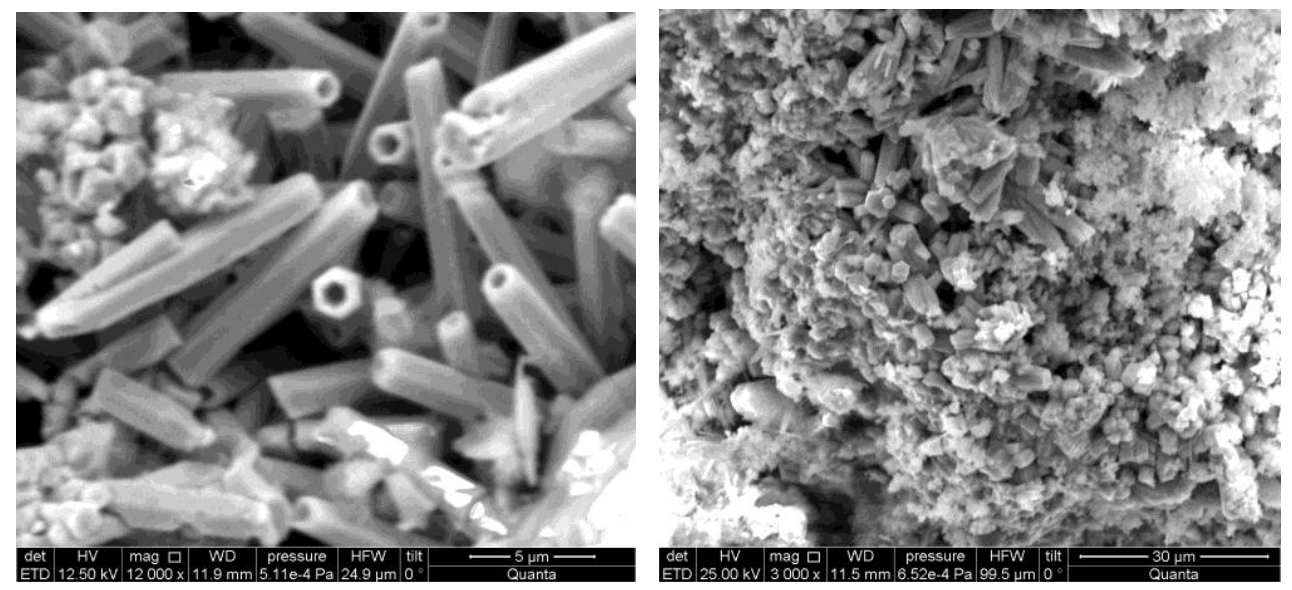

Fig. 4. Micrographs and composition of corrosion deposits mechanically removed from the pipe internal surface (galvanized steel pipe, DN $100 \mathrm{~mm}$, cathodic section).

Table 1. Elemental composition.

\begin{tabular}{|c|c|c|c|c|c|c|c|c|}
\hline \multirow{2}{*}{ Sample } & \multicolumn{7}{|c|}{ Elemental composition, Wt\% } \\
\cline { 2 - 9 } & $\mathrm{C}$ & $\mathrm{O}$ & $\mathrm{Fe}$ & $\mathrm{Zn}$ & $\mathrm{Na}$ & $\mathrm{Ca}$ & $\mathrm{P}$ & $\mathrm{Cl}$ \\
\hline $\mathrm{A}$ & - & 39,33 & - & 60,67 & - & - & - & - \\
\hline $\mathrm{B} 1(\mathrm{Zn})$ & 16,81 & 40,29 & 6,61 & 33,48 & 0,75 & - & 1,69 & 0,37 \\
$\mathrm{~B} 2(\mathrm{Fe})$ & - & 61,77 & 33,01 & 3,58 & - & 0,58 & 1,06 & - \\
\hline
\end{tabular}

These data suggest that calcium and magnesium ions at water temperatures up to $60^{\circ} \mathrm{C}$ and hardness up to $3 \mathrm{meq} / \mathrm{l}$ are likely to act as corrosion inhibitors, but not as part of a 
protective film on the pipe surface. These observations support a conclusion of V.A. Prisyazhnyuk, that iron and calcium carbonate are crystallographically incompatible [20].

However, this analysis of morphology and composition of corrosion deposits cannot fully explain an abnormally high corrosion rate exceeding 1-2 mm/year only due to the influence of the factors noted above.

Therefore, we need to consider other reasons as well. Many authors believe, that accelerated corrosion of steel and cast iron pipes is a result of bacteria and their metabolic products in the form of acids, gaseous products and complex compounds present in water [21-24].

Microbiological activity of microorganisms can cause or accelerate corrosion reaction $[21,22]$. The research [23] contains idea that development of microbiological corrosion is a result of transportation of different substances from the fluid to the metal surface. Microorganisms produce extracellular polymers that contribute to biofilm formation and adhesion of corrosion products. This process is known as tuberculation [23].

Two different classes of microorganisms cause steel pipes corrosion: aerobic and anaerobic types with completely different types of corrosion reactions [11, 24]. Microorganisms influence corrosion in several ways [22]: using oxygen by aerobic organisms leads to formation of anodic areas. Local differences in oxygen concentration shift potential of metal surfaces and lead to formation of local corrosion cells; using hydrogen by anaerobic organisms depolarizes the cathode through the cathodic reaction, which increases the rate of metal loss at the anode.

Around the tubercle base and inside the magnetite shell, oxygen concentration reduces, while anodic dissolution of iron occurs under a tubercle. Ferrous iron ions produced in the anode zone migrate through the sediment material upstream anions [23]. Due to increased concentration of anions, e.g. chlorides, eventually tubercle $\mathrm{pH}$ decreases. Thus, on the one hand tubercles prevent diffusion of oxygen and decrease the rate of oxygen corrosion, and on the other hand, bacteria and acid formed inside a tubercle lead to higher, compared to electrochemical, corrosion rate forming molecular hydrogen at the cathode.

Studying water quality indicators may confirm the idea that bacteria influence accelerated corrosion of pipes in the hot water supply system, because defining the total microbial number showed that hot water in the hot water supply system, from where the pipe sample shown in Fig. 1a was removed, contains bacteria.

So, the total microbial number was recorded at some points as 0 to $3.300 \mathrm{CFU} / \mathrm{ml}$ (while normally it should be maximum $50 \mathrm{CFU} / \mathrm{ml}$ in drinking water). At the same time, we did not discover thermotolerant and coliform bacteria. Such indicators may be an indirect sign of development of ferrobacteria in circulation loops of hot water supply systems.

\section{Conclusions}

1. The cause of primary corrosion of galvanized steel pipes in the hot water supply system was violation of requirements about stabilizing treatment of water before feeding it to the network.

2. Most probably, repairs to eliminate leaks without corresponding disinfection of piping contributed to appearance of ferrobacteria in the network, which became a secondary factor of corrosion development at an abnormally high rate.

3. The first and most straightforward solution would be adjustment of the $\mathrm{pH}$ value (up to $8.0-9.0$ ) by lime, caustic or carbon dioxide addition in order to increase Langelier index above 0 . 


\section{References}

1. P.S. Husband, J.B. Boxall, Water Res. 45(1), 113-124 (2011)

2. C.A. Della Rovere, R. Silva, C. Moretti, S.E. Kuri, Eng. Failure Analysis 33, 381-386 (2013)

3. F. Delaunois, F. Tosar, V. Vitry, Bioelectrochemistry 97, 110-119 (2014)

4. Z. Tang, S. Hong, W. Xiao, J. Taylor, Corrosion Sci. 48(2), 322-342 (2006)

5. P. Sarin, V.L. Snoeyink, J. Bebee, K.K. Jim, M.A. Beckett, W.M. Kriven, J.A. Clement, Water Res. 38(5), 1259-1269 (2004)

6. J. Ryl, J. Wysocka, K. Darowicki, Const. and Building Mat. 64, 246-252 (2014)

7. L. Tabandeh, G. Shams, A. Karami, Z. Atafar, H. Sharafi, A. Dargahi, F. Amirian, Int. J. of Pharmacy \& Technology 8(2), 13137-13154 (2016)

8. M. Fabbricino, G.V. Korshin, Water Res. 62, 136-146 (2014)

9. G.S. Vasyliev, Corrosion Sci. 98, 33-39 (2015)

10. P.A. Akolsin, Corrosion and metal protection for the heat power equipment (Energoizdat, Moscow, 1982)

11. H. Wang, C. Hu, X. Hu, M. Yang, J. Qu, Water Res. 46(4), 1070-1078 (2012)

12. T.L. Gerke, J.B. Maynard, M.R. Schock, D.L. Lytle, Corrosion Sci. 50(7), 2030-2039 (2008)

13. A. Andrianov, V. Chukhin, V. Orlov, CRC Press., 81-86 (2016)

14. B. McEnaney, D.C. Smith, Corrosion Sci. 20, 873-886 (1980)

15. V.S. Marangou, K. Savvides, Desalination 138, 251-258 (2001)

16. A.M. Shams El Din, Desalination 238, 166-173 (2009)

17. J. Liang, A. Deng, R. Xie, M. Gomez, J. Hu, J. Zhang, C.N. Ong, A. Adin, Desalination 322, 76-83 (2013)

18. H. Liu, K.D. Schonberger, C.-Y. Peng, J.F. Ferguson, E. Desormeaux, P. Meyerhofer, H. Luckenbach, G.V. Korshin, Water Res. 47(11), 3817-3826 (2013)

19. V. Chukhin, A. Andrianov, V. Orlov, International Conference and Exhibition 1B-1, 110 (2014)

20. V.A. Prisyazhniuk, Appl. Thermal Eng. 29(14-15), 3182-3188 (2009)

21. T. Ford, R. Mitchell, Adv. in Microbial Ecol. 11, 231-262 (1990)

22. S.E. Coetser, T.E. Cloete, Critical Reviews in Microbiology 31, 213-232 (2005)

23. W. Lee, Z. Lewandowski, P.H. Nielsen, W.A. Hamilton, Biofouling 8, 165-194 (1995)

24. A. Von Holy, International workshop on Industrial Biofouling and Biocorrosion (Mulheim, Germany, 1997) 